\title{
Organic matter decomposition in subtropical South America aquatic environments: a systematic and scientometric review
}

Decomposição de detritos orgânicos em ambientes aquáticos continentais em clima subtropical da América do Sul: uma revisão sistemática e cienciométrica

Pâmela Rodrigues Gayer ${ }^{1}$ (D), Andréa Luiza de Mattos de Moraes $^{1}$ (D),

Pablo Santos Guimarães ${ }^{2}$ (D); Fabiana Gonçalves Barbosa ${ }^{1}$ (D), Edélti Faria Albertoni ${ }^{1}$ (D) and

Luiz Ubiratan Hepp ${ }^{1,3^{*}}$ (D)

'Programa de Pós-graduação em Biologia de Ambientes Aquáticos Continentais, Universidade Federal do Rio Grande - FURG, Rio Grande, RS, Brasil

${ }^{2}$ Instituto de Ciências Biológicas, Universidade Federal do Rio Grande - FURG, Rio Grande, RS, Brasil

${ }^{3}$ Universidade Federal de Mato Grosso do Sul - UFMS, Campus de Três Lagoas, Três Lagoas, MS, Brasil

*e-mail: luizuhepp@gmail.com

Cite as: Gayer, P. R., Moraes, A. L. M., Guimarães, P. S., Barbosa, F. G., Albertoni, E. F. and Hepp, L. U. Organic matter decomposition in subtropical South America aquatic environments: a systematic and scientometric review. Acta Limnologica Brasiliensia, 2021, vol. 33, e104.

Abstract: Aim: To evaluate the general situation of studies on the decomposition of organic matter in aquatic environments in the subtropical region of South America. Methods: We compiled publications (1990-2018) with a combination of words referring to decomposition, debris, aquatic environments and South American countries with subtropical climate. The characteristics of the publications were analysed over time. Results: A total of 1,042 publications were found, with 106 specifically addressing the purpose of this study. For subtropical climates in South America, this research topic is incipient. Most studies were carried out in streams (39.6\%) and studied the decomposition process and associated invertebrates $(42.5 \%)$. There is a great deficiency of studies in lentic environments (e.g. lakes, 10\%). Conclusion: Studies on the decomposition of organic detritus in aquatic ecosystems in the subtropical region of South America are still emerging. While the knowledge about the role of shredders is more or less understood, the importance of microorganisms on the decomposition process still needs to be better evaluated. Finally, our study demonstrated that scientific collaboration boosted publication on the topic.

Keywords: leaf degradation; organic detritus; ecological processes; scientific production; aquatic metabolism.

Resumo: Objetivo: Avaliar a situação geral dos estudos sobre a decomposição da matéria orgânica vegetal em ambientes aquáticos continentais da região subtropical da América do Sul. Métodos: Utilizamos bancos de dados e compilamos publicações (1990-2018) utilizando combinaçóes de palavras referentes à decomposição, detritos, ambientes aquáticos e países da América do Sul com clima subtropical. As características das publicaçóes foram analisadas ao longo do tempo. Resultados: Um total de 1.042 publicaçóes foram encontradas, com 106 tratando especificamente do objetivo deste estudo. Em clima subtropical na América do Sul este tópico de pesquisa é incipiente. A 
maioria dos estudos foi realizada em riachos $(39,6 \%)$ e avaliou o processo de decomposição e a associaçáo de invertebrados (42,5\%). Há uma grande deficiência em estudos realizados em ambientes lênticos (e.g. lagos, 10\%). Conclusáo: Os estudos sobre a decomposiçáo de detritos orgânicos em ecossistemas aquáticos na regiáo subtropical da América do Sul são ainda emergentes. Enquanto o conhecimento sobre o papel dos fragmentadores é razoável, poucos estudos têm avaliado a importância de microrganismos no processo de decomposição. Finalmente, nosso estudo demonstrou que as colaboraçóes científicas impulsionaram as publicaçóes sobre o tema.

Palavras-chave: degradação foliar; detritos orgânicos; processos ecológicos; produção científica; metabolismo aquático.

\section{Introduction}

The decomposition of organic matter in aquatic environments is an important ecological process (Graça et al., 2015). This process is directly linked to biogeochemical cycles, contributing to nutrient cycling and to the maintenance of trophic webs in aquatic environments (Vannote et al., 1980). Decomposition also provides important ecosystem services such as controlling diseases and maintaining water quality and biodiversity (Cole et al., 2020).

The decomposition of organic matter is influenced by physical, chemical, and biological factors and is essential for the cycling of nutrients and energy flow (Farjalla et al., 1999; Hoorens et al., 2003; Gessner et al., 2010). In aquatic ecosystems, decomposition is mediated by processes that occur simultaneously including leaching, microbial conditioning, and fragmentation (Gessner et al., 1999). The leaching phase consists of the release of water-soluble compounds such as carbohydrates, phenols, and amino acids (Bärlocher, 2005). Microbial conditioning represents the colonization of organic matter by microorganisms including fungi and bacteria (Gonçalves Junior et al., 2006a). The fragmentation occurs both through physical abrasion of the water and through the action of invertebrate shredders (Gessner et al., 1999).

The source of organic matter in aquatic ecosystems can be of allochthonous or autochthonous origin (Webster \& Benfield, 1986). The autochthonous sources are algae and other photosynthetic organisms, which are more common in environments where there is plenty of light incidence (Neres-Lima et al., 2016; Neres-Lima et al., 2017). Although algae are common in lentic environments, aquatic macrophytes can contribute significantly depending on the characteristics of the environment (CunhaSantino et al., 2008). The allochthonous organic material may also be important in streams and small lakes, due to the interaction with the terrestrial environment (Webster \& Benfield, 1986; Pieczyńska, 1986). In lower order lotic environments, such as those at the highest portions of hydrographic basins, riparian vegetation is the main source of allochthonous organic matter (Vannote et al., 1980), and is composed mainly of tree leaves ( $-70 \%$; Gonçalves Junior et al., 2006b; Gonçalves Junior \& Callisto, 2013).

The decomposition of organic matter in aquatic ecosystems can vary according to the region's climate regime (Ward \& Stanford, 1982), water temperature (Irons et al., 1994; Song et al., 2013), invertebrate richness (Krevš \& Kučinskiene, 2017), and microbial dynamics (Suberkropp \& Klug, 1976). In temperate environments, decomposition tends to be influenced mainly by the presence of shredder invertebrates (Graça, 2001; Hieber \& Gessner, 2002; Boyero et al., 2011), as these organisms are adapted to cold environments (Cowan et al., 1983). In the tropics, the number of shredder invertebrates is decreased compared to temperate regions, with the decomposition being carried out mainly by microorganisms that decompose organic matter (Irons et al., 1994; Gonçalves Junior et al., 2007; Li et al., 2009). Important factors in the occurrence of shredders are altitudinal gradients, water temperature, characteristics of riparian vegetation, and water chemistry (Boyero et al., 2009; Yule et al., 2009).

Studies on organic matter decomposition have been carried out mainly in temperate and tropical zones (Abelho, 2001; Graça, 2001; Gonçalves Junior et al., 2007). On the other hand, in regions with a subtropical climate (especially in South America), studies on organic matter decomposition are incipient. In this sense, this systematic and scientometric review focuses on the survey of existing information, precisely, in the subtropical region of South America. South American regions with a subtropical climate have an average monthly air temperature over $10{ }^{\circ} \mathrm{C}$ for eight to twelve months of the year and in the coldest month the temperature is normally below $18{ }^{\circ} \mathrm{C}$ (Belda et al., 2014). The rainfall in these regions vary in amplitude depending on the meso- or micro-region, with dry summers, humid winters, or well-distributed rains throughout the year (Belda et al., 2014). In these 
places, the vegetation includes different South American biomes, especially Atlantic Forest and Pampa biomes, with transition zones existing between these two biomes and tropical forests (Oliveira-Filho et al., 2015).

In this study, we did a systematic and scientometric review to assess studies on the decomposition of organic matter in continental aquatic environments in the subtropical region of South America. We evaluated the temporal patterns of scientific production, the relative contribution of the countries of South America, the existence of national and international scientific cooperation, and identified the main objectives of the studies.

\section{Material and Methods}

\subsection{Selection of publications}

We conducted the research using the Web of Science (Clarivate Analytics) and Scopus (Elsevier) databases in June 2019. We used these two bases to expand our research, given that some South American journals are not indexed in Web of Science. We searched for publications that contained the following combination of terms in the title, abstract, or keywords: (decomposition or degradation or decomposing) and (leaf* or macrophyte* or "aquatic plant*" or litter or "leaf breakdown" or "allochthonous material" or "autochthonous material" or "riparian vegetation") and (river* or lake* or stream* or lentic* or lotic* or wetland* ${ }^{*}$ or reservoir* or pond* ${ }^{*}$ or floodplain* or lagoon* or mangrove* or estuary* or estuarine* or freshwater*) and (subtropical or Brazil* or Paraguay* or Uruguay* or Argentin\$ or Chile* or Venezuela* or Colombia* or Ecuador* or Peru* or Bolivia*). We used $\$$ and ${ }^{*}$ to compile variations of the term, however, ${ }^{*}$ represents any group of characters, including no characters, while $\$$ represents no characters or one character. In addition, we used the CU field label on the Web of Science and AFFILCOUNTRY on Scopus to define the authors' affiliation and indicate the countries (Brazil, Paraguay, Uruguay, Argentina, Chile, Venezuela, Colombia, Ecuador, Peru, or Bolivia) in South America. Our research considered publications from January 1990 to December 2018. As the Web of Science database abstracts are available only from 1991 onwards, we considered only the Scopus database from 1990, while the search on the Web of Science database started in 1991.

We reviewed the titles, abstracts and study areas to select the publications corresponding to the topic under analysis. Review articles were not considered in this analysis. To define the study area of publications and selected only countries with a subtropical climate, we used group C of the KöppenTrewartha climate classification (Belda et al., 2014; Figure 1). In addition, we collected the geographical coordinates of the study areas of publications and overlayed them on the climate classification map using the $\operatorname{ArcGIS}^{\bullet}$ software. From this overlap, we selected the publications that were used in the final analysis. After evaluating each publication individually, we considered only the publications that met the proposal of this study, that is, only those conducted in the subtropical climate of South America. We identified 1042 publications and, after applying the selection criteria and eliminating duplicate publications and/or studies in regions that were not of a subtropical climate in the two databases, we obtained 106 publications for our analysis.

In each selected publication we extracted general and specific information: year of publication, scientific journal where the study was published, nationality of the authors, country where the study was carried out, type of environment (i.e., wetland, river, lake, mangrove), organic matter source (i.e., autochthonous or allochthonous), experimental or field study, and objectives of the study. When evaluating the objectives of the studies, we considered whether the focus of the publication was on microorganisms, invertebrates, and loss of mass. In addition, we observed whether the objectives of the studies contemplated the entry of allochthonous material (i.e., litterfall), environmental effects on the decomposition process, or comparison of the decomposition of two or more plant species. To study the temporal trend of publications during the period of interest, we plotted the number of articles published over the years and examined the trend using a polynomial model. The type of scientific collaboration between countries was determined based on the country of the authors for each publication. The term Single Country Publication (SCP) was attributed to publications with corresponding author and co-authors belonging to the same country; Multiple Country Publication (MCP) was attributed to publications where the corresponding author and co-authors belonged to different countries (Liu et al., 2011). We analysed the data using the $\mathrm{R}$ environment $(\mathrm{R}$ Core Team, 2019) with the 'bibliometrix' package (Aria \& Cuccurullo, 2017). 


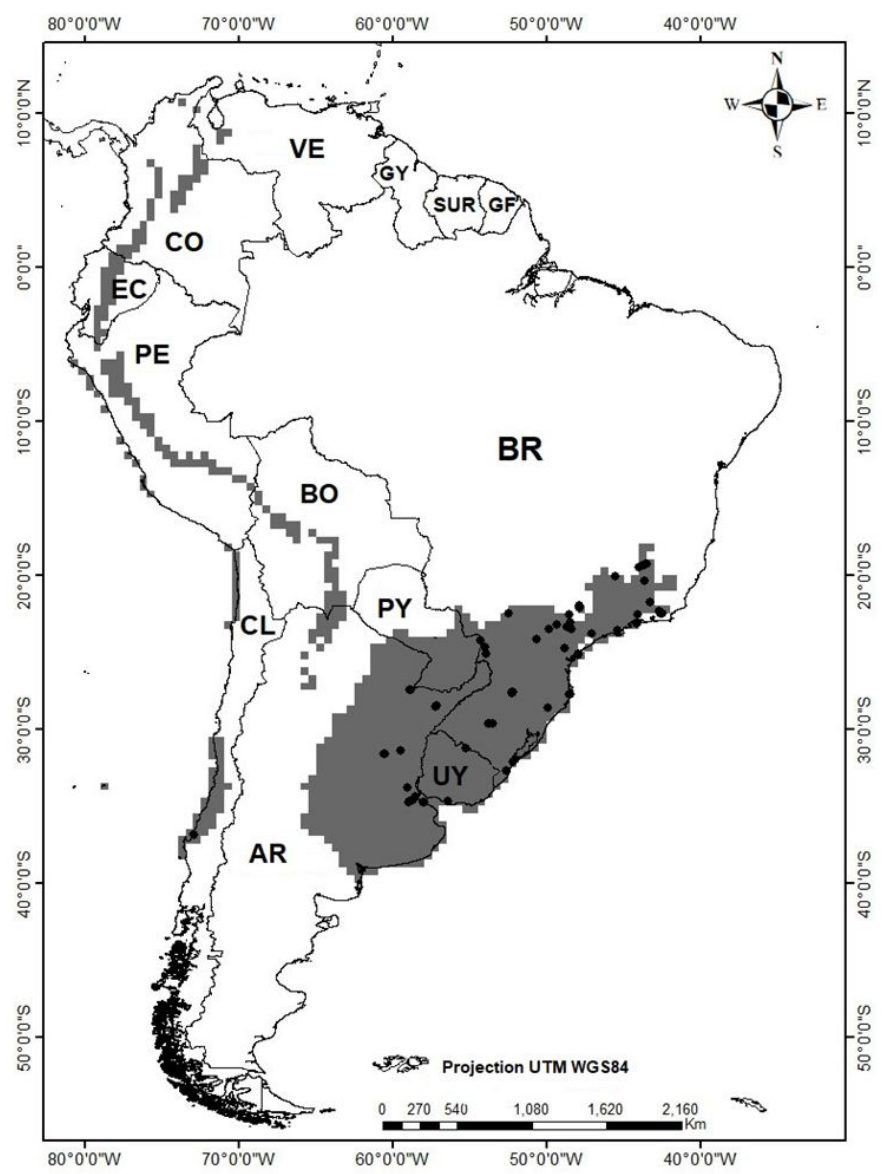

Figure 1. Map of the regions with subtropical climate in South America, based on the Köppen-Trewartha climate classification. Gray area = subtropical regions. Points: origin of the publications. AR: Argentina; UY: Uruguay; BR: Brazil; PY: Paraguay; CL: Chile; BO: Bolivia; PE: Peru; CO: Colombia; VE: Venezuela; EC: Ecuador; GY: Guyana; SUR: Suriname; GF: French Guiana.

\section{Results}

After our bibliographic survey, we identified a total of 1,042 publications on the proposed topic. From the reading of the study area, we selected the studies conducted in the in the subtropical region of South America, resulting in 129 publications. We subsequently performed a new screening for works focusing on aquatic ecosystems, ending with a total of 106 publications ( $10.1 \%$ of the original set). We observed an increase in the number of publications from 1990 to 2018 (Figure 2).

The studies were published in 61 scientific journals. The scientific journal "Brazilian Journal of Biology" published the largest number of articles (9.4\%; Table 1). Of the total scientific journals, $19.8 \%$ are from South American countries, while $80.2 \%$ of the scientific journals are from North America, Europe, and Oceania.

Among the 10 countries in South America that have regions with a subtropical climate, we observed

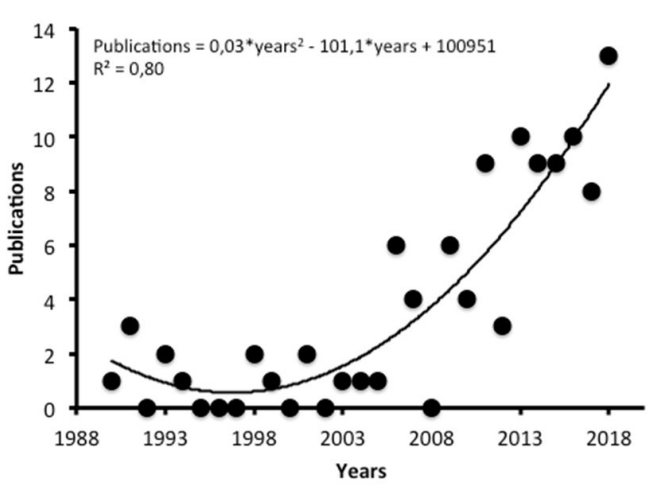

Figure 2. Number of publications on decomposition in subtropical South American aquatic environments (1990-2018).

studies carried out in Brazil (72.6\% of publications), Argentina (21.5\%), Ecuador (3.7\%), Uruguay (3.7\%), Chile (1.9\%), and Colombia (1.9\%). The sum of these publications exceeds $100 \%$ because studies carried out in more than one country were 
Table 1. Journals with more than one publication on decomposition in subtropical South American aquatic environments, during the period between 1990 and 2018, using the Scopus and the Web of Science databases.

\begin{tabular}{cccc}
\hline Journal & JIF & Number of publications & Country \\
\hline Brazilian Journal of Biology & 0.98 & 10 & Brazil \\
Limnologica & 2.05 & 5 & Netherlands \\
Hidrobiológica & 0.23 & 4 & Mexico \\
Marine and Freshwater Research & 1.85 & 4 & Australia \\
Acta Limnologica Brasiliensia & $0.35^{*}$ & 4 & Brazil \\
Hydrobiologia & 2.32 & 4 & Netherlands \\
International Review of Hydrobiology & 2.53 & 4 & UK \\
Aquatic Botany & 2.14 & 3 & Netherlands \\
Ecologia Austral & $0.20^{*}$ & 3 & Argentina \\
Journal of Limnology & 1.60 & 3 & Italy \\
Wetlands & 1.85 & 3 & Netherlands \\
Annales de Limnologie - Int. J. of Limnology & 0.82 & 2 & France \\
Brazilian Journal of Microbiology & 2.85 & 2 & Brazil \\
Ecological Indicators & 4.49 & 2 & Netherlands \\
Freshwater Biology & 3.40 & 2 & UK \\
Fundamental and Applied Limnology & 0.98 & 2 & Germany \\
Interciencia & 0.26 & 2 & Venezuela \\
Journal of Insect Science & 1.44 & 2 & USA \\
Limnetica & 0.57 & 2 & Spain \\
River Research and Applications & 1.95 & 2 & USA \\
Other journals (only one publication) & & 41 & \\
\hline
\end{tabular}

JIF= Journal impact factor (2018). *Scimago Journal \& Country Rank is shown for journals without JIF.

Table 2. Countries (first author) that published studies about decomposition in subtropical South American aquatic environments during the period between 1990 and 2018.

\begin{tabular}{ccccc}
\hline Country & TP & SCP & MCP & Country \\
\hline Brazil & 74 & 66 & 8 & Argentina, Australia, Canada, Portugal, Spain, Scotland, USA \\
Argentina & 22 & 20 & 2 & Brazil, Australia \\
Ecuador & 2 & 1 & 1 & Argentina \\
Portugal & 2 & 0 & 2 & Germany \\
Uruguay & 2 & 1 & 1 & Brazil \\
USA & 1 & 0 & 1 & Argentina \\
Canada & 1 & 0 & 1 & Chile, Portugal \\
Colombia & 1 & 1 & 0 & Brazil \\
Spain & 1 & 0 & 1 & \\
Total & $\mathbf{1 0 6}$ & $\mathbf{8 9}$ & $\mathbf{1 7}$ & \\
\hline
\end{tabular}

TP = Total publications; SCP = Single Country Publications: Publications with authors from a single country; MCP = Multiple Country Publications: Publications with authors from different countries.

assigned to each one separately in the analysis. When considering scientific collaboration, only $16 \%$ of the articles has international collaboration, of which $47 \%$ involve Brazilian authors (Table 2). During the period considered in this study, Brazilian authors have collaborated with authors from countries in South and North America, Oceania and Europe (Table 2).

Most of the studies were carried out in lotic systems (50.9\% of publications) (Table 3 ). However, we observed studies carried out on lentic systems (29.2\%), laboratory experiments (16.9\%), and phytotelma (2.8\%). Among the lotic systems, streams were the most studied ecosystems (77.7\%),
Table 3. Systems and ecosystems where decomposition studies were carried out in subtropical South American aquatic environments.

\begin{tabular}{ccc}
\hline System & Ecosystem & $\begin{array}{c}\text { Number of } \\
\text { publications }\end{array}$ \\
\hline Lotic & Stream & 42 \\
& River & 9 \\
Lentic & Estuary & 3 \\
& Wetland & 10 \\
& Lake & 11 \\
& Reservoir & 9 \\
Laboratory & Mangrove & 1 \\
Phytothelmata & Mesocosm & 18 \\
Total & Bromeliaceae & 3 \\
\hline
\end{tabular}


Table 4. Description of the objectives and number of publications about decomposition in aquatic environments at the subtropical region of South America.

\begin{tabular}{|c|c|}
\hline Objectives & Number of publications (frequency, \%) \\
\hline Studies that evaluated only the litterfall & $1(0.9 \%)$ \\
\hline Studies that evaluated litterfall and leaf decomposition rates & $3(2.8 \%)$ \\
\hline $\begin{array}{l}\text { Studies that evaluated litterfall and invertebrate fauna associated with the } \\
\text { decomposition process }\end{array}$ & $2(1.9 \%)$ \\
\hline $\begin{array}{c}\text { Studies that evaluated litterfall, invertebrate fauna and microorganisms } \\
\text { associated with the decomposition process }\end{array}$ & $7(6.6 \%)$ \\
\hline Studies that described the decomposition of debris over time & $11(10.4 \%)$ \\
\hline Studies comparing the decomposition rates of different plant species & $11(10.4 \%)$ \\
\hline $\begin{array}{l}\text { Studies that assessed the effects of environmental variables on } \\
\text { decomposition rates }\end{array}$ & $12(11.3 \%)$ \\
\hline $\begin{array}{l}\text { Studies that evaluated the decomposition rates and invertebrate fauna } \\
\text { associated with the process }\end{array}$ & $45(42.5 \%)$ \\
\hline $\begin{array}{l}\text { Studies that evaluated the decomposition rates and the microorganisms } \\
\text { associated with the process }\end{array}$ & $9(8.5 \%)$ \\
\hline $\begin{array}{c}\text { Studies that evaluated decomposition rates, invertebrate fauna and } \\
\text { microorganisms associated with the process }\end{array}$ & $5(4.7 \%)$ \\
\hline
\end{tabular}

while wetlands (32\%), lakes (34\%), and reservoirs (29\%) where the most studied lentic ecosystems (Table 3). The leaves of aquatic macrophytes were the most frequently used source of organic matter in laboratory studies and in lentic environments. In phytothelmata and lotic environments, leaf detritus from tree species (allochthonous origin) were the most studied substrates.

When analysing the objectives of the publications, we observed that the majority $(42.5 \%)$ sought to evaluate the rates of decomposition and associated invertebrates (Table 4). In addition, $10.4 \%$ of publications aimed to describe the decomposition process, $10.4 \%$ compared the decomposition rate of two or more species, and $11.3 \%$ sought to describe environmental effects on the rates of decomposition. Only $6.6 \%$ of the publications contemplated organic matter input (i.e., litterfall) in the aquatic environments and the participation of invertebrates and microorganisms. Only one publication had the exclusive objective of describing the litterfall of tree species (Table 4). We observed that most of the publications (68.8\%) evaluated the participation of biological components on the decomposition process (i.e., microorganisms or invertebrates). Of these, $45.2 \%$ of publications considered only invertebrates, 9.4\% evaluated only microorganisms, and another $14.1 \%$ evaluated the participation of both biological components. Among the publications that evaluated the participation of invertebrates, $81 \%$ considered all groups and $19 \%$ evaluated only one specific group in the decomposition process (e.g., Chironomidae, Aeglidae, Plecoptera, or Trichoptera). Among the publications that evaluated the microbial component,
$48 \%$ evaluated the total microbial biomass, $40 \%$ exclusively evaluated fungi, and $12 \%$ exclusively evaluated bacteria. The publications that did not evaluate the biological component (31.1\%) focused on studying the leaching process, decay rates, the effect of the "litter quality" or chemical composition of organic matter, and the limnological characteristics of water on the decomposition process.

\section{Discussion}

Our study demonstrated that the number of publications on decomposition in subtropical South American aquatic ecosystems has increased, especially in the last 13 years. Since the beginning of the 20th century, several countries in South America have created scientific laboratories and institutions where local groups began to carry out original experimental studies recognized by the international scientific community with important contributions to knowledge (Canizares-Esguerra \& Cueto, 2002). However, we note that the majority of publications in this review were concentrated in Brazil and Argentina. According to May (1997), this high scientific production may be associated with economic development. In fact, Argentina and Brazil are the two countries with the largest economies in South America (World Bank, 2021). Additionally, previous systematic reviews on aquatic ecology in South America or Neotropics showed that Argentina and Brazil were the most productive countries (Padial et al., 2008; Barbosa 2014; Dominguez \& Santos, 2014; Kandus et al., 2017). The increase in publications across the years can be associated with investments in education, 
science, and technology in Latin America and the increase in scientific collaboration. Since the 2000s, Brazil has expanded its scientific production (Huggett, 2012), and this has been reflected in the publication of studies in Aquatic Ecology (Dias et al., 2016; Silva \& Perbiche-Neves, 2017; Junqueira et al., 2020; Tourinho et al., 2020). This expansion can be linked to the intensification of the networks of scientific collaboration between Brazilian researchers (Leta \& Chaimovich, 2002) and, according to Sidone et al. (2016), geographical proximity plays an important role in collaboration networks in Brazil. For example, the first "Seminário sobre Estudos Limnológicos em Clima Subtropical" organized at the Universidade Federal do Rio Grande in 2008 had the participation of researchers and students from the three southern states of Brazil and sought to promote an approximation between research groups interested in subtropical limnology. The increase in publications in recent years coincides with the holding of these biannual scientific meetings. Public financial support and the holding of scientific meetings boosted scientific production on subtropical limnology. Despite the delay between the execution and publication of a scientific work, we suggest that the financial support and the promotion of scientific meetings favoured an increase on the number of studies about decomposition processes in subtropical aquatic environments.

We found that Brazil is the main contributor on publications about decomposition. In addition to the expansion of inter-institutional research groups, the increase in Brazilian scientific production is related to incentive policies established in the last decade (Regalado, 2010). The government's scientific development agencies (e.g., Coordenação de Aperfeiçoamento de Pessoal de Nível Superior, Conselho Nacional de Desenvolvimento Científico e Tecnológico, and State Foundations for Research) have invested significant amounts in scientific and technological development, as well as in the qualification of personnel, at various levels of academia (Borges, 2008; Dudziak, 2018). This is reflected in the increase in Brazilian scientific production in different areas, including Limnology (Melo et al., 2006; Walz, 2010). Although our research focused on South American publications, we found that the publications were not restricted to scientific journals from countries in South America. There are articles published in journals from North America and Europe, demonstrating the interest of the global scientific community for the knowledge generated in South America, following the general pattern noted by Tourinho et al. (2020) regarding threatened freshwater fish species in Brazil.

Among the South American countries, only Brazil, Argentina, Ecuador and Uruguay published works in collaboration with researchers from other countries. The low percentage of collaboration $(16 \%)$ suggests that academic research communities are still poorly connected with international collaborators. This gap has been mentioned by other authors who have carried out scientific studies on Brazilian Limnology (Melo et al., 2006), aquatic macrophytes (Padial et al., 2008), and invasive species (Barbosa, 2014). The low international collaboration in the production of articles reflects past difficulties in carrying out joint work. This pattern may be related to the fact that the realization of international collaboration, generally, results of the global view of the researcher (Neves et al., 2019). In addition, the existence of linguistic and cultural barriers and the geographical distance between countries makes it difficult to interact with foreign partners. On the other hand, these facts may favour partnerships between researchers from the same country (Sidone et al., 2016).

Lotic ecosystems (especially streams) presented the largest number of publications about decomposition. This is probably because the relevance of allochthonous organic material as energy source to streams (Vannote et al., 1980; Trevisan \& Hepp, 2007; Tonin et al., 2018). Also, the high level of anthropization that streams undergo, especially due to the degradation of riparian vegetation (Hepp et al., 2016; Biasi et al., 2020), may be another reason for the great interest in conducting studies at these ecosystems. Lentic environments were studied in approximately $30 \%$ of the analysed publications. The lowest percentage of studies on decomposition in lentic environments may be related to the greatest interest in carrying out studies on primary productivity and fish communities at these environments (e.g., Quiros, 1990; Pereira et al., 2012; Guimarães et al., 2013; Albertoni et al., 2014).

As for the organisms involved in the decomposition process, our results showed that almost half of the publications considered the participation of invertebrates in the decomposition process. Despite the low percentage of shredders in the functional composition of aquatic invertebrates (Tonin et al., 2014), this group plays a fundamental role in the transformation of coarse particulate organic matter into fine particulate organic 
matter (Tonello et al., 2016). We also found that studies describing the decomposition process of aquatic macrophytes or allochthonous organic matter were common. Considering that studies on decomposition in the subtropical region of South America are recent, the description of the process is a basic and fundamental objective for advancing more applied research. The percentage of studies analysing microorganisms is low due to the difficulty of studying bacteria and aquatic fungi, in addition to the small number of researchers in this area (Gulis \& Bärlocher, 2017; Raja et al., 2018). The choice of organic material used in the decomposition experiments was based on the frequency of this material in the areas adjacent to the studied environments (Fontana et al., 2020; Biasi et al., 2020).

We observed a great number of investigations on invertebrates associated with leaf detritus. The use of detritus as a food resource or substrate for invertebrates is widely discussed in the literature (Graça, 2001; Telöken et al., 2014; Albertoni et al., 2018). However, a low percentage of the invertebrate community is directly related to the process of transforming organic matter (i.e., shredders) (Ligeiro et al., 2010; Telöken et al., 2011; Carvalho et al., 2015; Albertoni et al., 2018). The larvae of the Phylloicus genus (Calamoceratidae, Trichoptera) are the shredder invertebrates that are widely found in aquatic environments in subtropical South America (Holzenthal et al., 2007) and we found that it is the most-studied genus because of its wide distribution.

Our analysis did not detect decomposition studies within broader topics, such as climate change, diversity loss, or relationships between diversity of resources and diversity of detritivores. Considering that even basic studies on decomposition in subtropical aquatic environments in South America are still scarce, studies aiming to answer broader questions are practically non-existent. Alternatively, projects on a global scale (e.g., Boyero et al., 2011; Tiegs et al., 2019) may inhibit the interest in carrying out more local studies, such as those in South America. Despite recent financial investments in science in some South American countries such as Brazil, increased financial resources in technology are necessary to set up and maintain research groups. This would facilitate the conduction of studies aiming to answer broader questions, such as the effects of climate change or other anthropogenic influences.
Although the decomposition process is complex (Gessner et al., 1999), few studies considered all stages (i.e., leaching, microbiological conditioning, and fragmentation) of the decomposition process. We also found that the understanding of the decomposition process mediated by microorganisms is still underdeveloped in the South American region, probably due to the low number of researchers specializing in the identification of fungi, as well as the analytical complexity of bacterial studies (Gulis \& Bärlocher, 2017).

We observed a low number of studies that focused on decomposition processes in aquatic environments at the subtropical regions of South America. However, it is clear that the number of publications is increasing, indicating the growing interest of the scientific community on this subject. Our analysis highlighted some important directions for future studies, such as the need to expand international collaboration, the need to advance studies focusing on microorganisms and on lentic ecosystems, as well as studies on gut content or isotopic analysis of detritivores to better understand their food preferences.

\section{Acknowledgment}

We thank Dr. Aline Barbosa da Silva for her help in superimposing the coordinates of the studies on the map of the climatic classification. We thank professors Dr. Cleber Palma Silva and Dr. Ng Haig They for reviewing and considering the manuscript. This work was carried out with the support of the Coordenação de Aperfeiçoamento de Pessoal de Nível Superior - Brazil (CAPES) - Financing Code 001. LUH receives financial support from Conselho Nacional de Desenvolvimento Científico e Tecnológico (CNPq) process \#421632/2016-0) and productivity grant (process \#305203/2017-7).

\section{References}

ABELHO, M. From litterfall to breakdown in streams: a review. TheScientific WorldJournal, 2001, 1, 656680. http://dx.doi.org/10.1100/tsw.2001.103. PMid:12805769.

ALBERTONI, E.F., HEPP, L.U., CARVALHO, C. and PALMA-SILVA, C. Invertebrate composition in submerged macrophyte debris: habitat and degradation time effects. Ecología Austral, 2018, 28, 93-103.

ALBERTONI, E.F., PALMA-SILVA, C., TRINDADE, C.R.T. and FURLANETTO, L.M. Field evidence of the influence of aquatic macrophytes on water quality in a shallow eutrophic lake over a 13year period. Acta Limnologica Brasiliensia, 2014, 
26(2), 176-185. http://dx.doi.org/10.1590/S2179975X2014000200008.

ARIA, M. and CUCCURULLO, C. Bibliometrix: An R-tool for comprehensive science mapping analysis. Journal of Informetrics, 2017, 11(4), 959-975. http:// dx.doi.org/10.1016/j.joi.2017.08.007.

BARBOSA, F.G. The scientific literature on Limnoperna fortunei (Dunker 1857) from 1982 to 2012. Anais da Academia Brasileira de Ciências, 2014, 86(3), 1373-1384. http://dx.doi.org/10.1590/00013765201420130281 . PMid:25140499.

BÄRLOCHER, F. Leaching. In: M.A.S. GRAÇA, F. BÄRLOCHER and M.O. GESSNER. Methods to study litter decomposition: a practical guide. Dordrecht: Springer, 2005. http://dx.doi.org/10.1007/1-40203466-0_5.

BELDA, M., HOLTANOVÁ, E., HALENKA, T. and KALVOVÁ, J. Climate classification revisited: from Köppento Trewartha. Climate Research, 2014, 59(1), 1-13. http://dx.doi.org/10.3354/cr01204.

BIASI, C., FONTANA, L.E., RESTELLO, R.M. and HEPP, L.U. Effect of invasive Hovenia dulcis on microbial decomposition and diversity of hyphomycetes in Atlantic forest streams. Fungal Ecology, 2020, 44, 100890. http://dx.doi. org/10.1016/j.funeco.2019.100890.

BORGES, S.H. A importância do ensino de pósgraduação na formação de recursos humanos para o estudo da biodiversidade no Brasil: um estudo de caso na ornitologia. Biota Neotropica, 2008, 8(1), 21-27. http://dx.doi.org/10.1590/S167606032008000100002 .

BOYERO, L., PEARSON, R.G., GESSNER, M.O., BARMUTA, L.A., FERREIRA, V., GRAÇA, M.A., DUDGEON, D., BOULTON, A.J., CALLISTO, M., CHAUVET, E., HELSON, J.E., BRUDER, A., ALBARIÑO, R.J., YULE, C.M., ARUNACHALAM, M., DAVIES, J.N., FIGUEROA, R., FLECKER, A.S., RAMÍREZ, A., DEATH, R.G., IWATA, T., MATHOOKO, J.M., MATHURIAU, C., GONÇALVES JUNIOR, J.F., MORETTI, M.S., JINGGUT, T., LAMOTHE, S., M'ERIMBA, C., RATNARAJAH, L., SCHINDLER, M.H., CASTELA, J., BURIA, L.M., CORNEJO, A., VILLANUEVA, V.D. and WEST, D.C. A global experiment suggests climate warming will not accelerate litter decomposition in streams but might reduce carbon sequestration. Ecology Letters, 2011, 14(3), 289-294. http://dx.doi.org/10.1111/j.14610248.2010.01578.x. PMid:21299824.

BOYERO, L., RAMIREZ, A., DUDGEON, D. and PEARSON, R.G. Are tropical streams really different? Journal of the North American Benthological Society, 2009, 28(2), 397-403. http://dx.doi. org/10.1899/08-146.1.

CANIZARES-ESGUERRA, J. and CUETO, M. Latin American science: The long view. NACLA Report on the Americas, 2002, 35(5), 18-22. http://dx.doi.org/ 10.1080/10714839.2002.11722530.
CARVALHO, C., HEPP, L.U., PALMA-SILVA, C. and ALBERTONI, E.F. Decomposition of macrophytes in a shallow subtropical lake. Limnologica, 2015, 53, 1-9. http://dx.doi.org/10.1016/j.limno.2015.04.003.

COLE, L.J., STOCKAN, J. and HELLIWELL, R. Managing riparian buffer strips to optimise ecosystem services: A review. Agriculture, Ecosystems \& Environment, 2020, 296, 106891. http://dx.doi. org/10.1016/j.agee.2020.106891.

COWAN, C.A., OSWOOD, M.W., BUTTIMORE, C.A. and FLANAGAN, P.W. Processing and macroinvertebrate colonization of detritus in an Alaskan subarctic stream. Holarctic Ecology, 1983, 6(4), 340-348. http://dx.doi. org/10.1111/j.1600-0587.1983.tb01228.x.

CUNHA-SANTINO, M.B., SCIESSERE, L. and BIANCHINI JUNIOR, I. As atividades das enzimas na decomposição da matéria orgânica particulada em ambientes aquáticos continentais. Oecologia Brasiliensis, 2008, 12(1), 30-41.

DIAS, M.S., ZUANON, J., COUTO, T.B.A., CARVALHO, M., CARVALHO, L.N., ESPÍRITO-SANTO, H.M.V., FREDERICO, R., LEITÃO, R.P., MORTATI, A.F., PIRES, T.H.S., TORRENTE-VILARA, G., VALE, J., ANJOS, M.B., MENDONÇA, F.P. and TEDESCO, P.A. Trends in studies of Brazilian stream fish assemblages. Natureza \& Conservação, 2016, 14(2), 106-111. http://dx.doi.org/10.1016/j.ncon.2016.06.003.

DOMÍNGUEZ, E. and SANTOS, D.A. Co-authorship networks (and other contextual factors) behind the growth of taxonomy of South American Ephemeroptera: a scientometric approach. Zootaxa, 2014, 3754(1), 59-85. http://dx.doi.org/10.11646/ zootaxa.3754.1.3. PMid:24869680.

DUDZIAK, E.A. Quem financia a pesquisa brasileira? Um estudo InCites sobre o Brasil e a USP [online]. São Paulo: SIBiUSP, 2018 [viewed 17 Jan. 2021]. Available from http://www.sibi.usp.br/noticias/ quem-financia-a-pesquisa-brasileira-um-estudoincites-sobre-o-brasil-e-a-usp/

FARJALLA, V.F., MARINHO, C.C. and ESTEVES, F.A. Uptake of oxygen in the initial stages of decomposition of aquatic macrophytes and detritus from terrestrial vegetation in a tropical coastal lagoon. Acta Limnologica Brasiliensia, 1999, 11(2), 185-193.

FONTANA, L.E., TONELLO, G., RESTELLO, R.M. and HEPP, L.U. A presença da agricultura altera a decomposição foliar e a composição das comunidades de invertebrados aquáticos em riachos subtropicais. Revista Perspectivas (Cochambamba), 2020, 44(165), 7-20. http://dx.doi.org/10.31512/persp.v.44.n.165. 2020.70.p.7-20.

GESSNER, M.O., CHAUVET, E. and DOBSON, M. A perspective on leaf litter breakdown in streams. Oikos, 1999, 85(2), 377-384. http://dx.doi. org/10.2307/3546505. 
GESSNER, M.O., SWAN, C.M., DANG, C.K., MCKIE, B.G., BARDGETT, R.D., WALL, D.H. and HATTENSCHWILER, S. Diversity meets decomposition. Trends in Ecology \& Evolution, 2010, 25(6), 372-380. http://dx.doi.org/10.1016/j. tree.2010.01.010. PMid:20189677.

GONÇALVES JUNIOR, J.F. and CALLISTO, M. Organic-matter dynamics in the riparian zone of a tropical headwater stream in Southern Brasil. Aquatic Botany, 2013, 109, 8-13. http://dx.doi. org/10.1016/j.aquabot.2013.03.005.

GONÇALVES JUNIOR, J.F., FRANÇA, J.S., MEDEIROS, A.O., ROSA, C.A. and CALLISTO, $M$. Leaf breakdown in a tropical stream. International Review of Hydrobiology, 2006a, 91(2), 164-177. http://dx.doi.org/10.1002/iroh.200510826.

GONÇALVES JUNIOR, J.F., FRANÇA, J.S. and CALLISTO, M. Dynamics of allochthonous organic matter in a tropical Brazilian headstream. Brazilian Archives of Biology and Technology, 2006b, 49(6), 967-973. http://dx.doi.org/10.1590/S151689132006000700014

GONÇALVES JUNIOR, J.F., GRAÇA, M.A.S. and CALLISTO, M. Litter decomposition in a Cerrado savannah stream is retarded by leaf toughness, low dissolved nutrients and a low density of shredders. Freshwater Biology, 2007, 52(8), 1440-1451. http:// dx.doi.org/10.1111/j.1365-2427.2007.01769.x.

GRAÇA, M.A.S. The role of invertebrates on leaf decomposition in streams: a review. International Review of Hydrobiology, 2001, 86(4-5), 383-393. http://dx.doi. org/10.1002/1522-2632(200107)86:4/5<383::AIDIROH383>3.0.CO;2-D.

GRAÇA, M.A., FERREIRA, V., CANHOTO, C., ENCALADA, A.C., GUERRERO-BOLAÑO, F., WANTZEN, K.M. and BOYERO, L. A conceptual model of litter breakdown in low order streams. International Review of Hydrobiology, 2015, 100(1), 1-12. http://dx.doi.org/10.1002/iroh.201401757.

GUIMARÃES, P.S., ZIGIOTTO, L., GARCIA, M., DELLAMANO-OLIVEIRA, M.J., VIEIRA, A.A. and GIROLDO, D. Phytoplankton relationship with bacterioplankton, dissolved carbohydrates and water characteristics in a subtropical coastal lagoon. Journal of Limnology, 2013, 72(3), 543-554. http:// dx.doi.org/10.4081/jlimnol.2013.e45.

GULIS, V. and BÄRLOCHER, F. Fungi: Biomass, Production, and Community Structure. In. F.R. HAUER and G.A. LAMBERTI. Methods in Stream Ecology. Elsevier, 2017, pp. 177-192. http://dx.doi. org/10.1016/B978-0-12-416558-8.00010-X

HEPP, L.U., URBIM, F.M., TONELLO, G., LOUREIRO, R., SAUSEN, T.L., FORNEL, R. and RESTELLO, R.M. Influence of land-use on structural and functional macroinvertebrate composition communities associated on detritus in Subtropical Atlantic Forest streams. Acta Limnologica Brasiliensia, 2016, 28(0), 1-10. http://dx.doi. org/10.1590/S2179-975X0616.
HIEBER, M. and GESSNER, M.O. Contribution of stream detritivores, fungi, and bacteria to leaf breakdown based on biomass estimates. Ecology, 2002, 83(4), 1026-1038. http://dx.doi. org/10.1890/0012-9658(2002)083[1026:COSDF A]2.0.CO;2.

HOLZENTHAL, R.W., BLAHNIK, R.J., PRATHER, A.L. and KJER, K.M. Order Trichoptera Kirby, 1813 (Insecta), Caddisflies. Zootaxa, 2007, 1668(1), 639698. http://dx.doi.org/10.11646/zootaxa.1668.1.29.

HOORENS, B., AERTS, R. and STROETENGA, M. Does initial litter chemistry explain litter mixture effects on decomposition? Oecologia, 2003, 137(4), 578-586. http://dx.doi.org/10.1007/s00442-0031365-6. PMid:14505026.

HUGGETT, S. The rise of Latin American science. Research Trends, 2012, 31, 15-18.

IRONS, J.G., OSWOOD, M.W., STOUT, R.J. and PRINGLE, C.M. Latitudinal patterns in leaf litter breakdown: is temperature really important? Freshwater Biology, 1994, 32(2), 401-411. http:// dx.doi.org/10.1111/j.1365-2427.1994.tb01135.x.

JUNQUEIRA, N.T., MAGNAGO, L.F. and POMPEU, P.S. Assessing fish sampling effort in studies of Brazilian streams. Scientometrics, 2020, 123(2), 841-860. http://dx.doi.org/10.1007/s11192-02003418-4.

KANDUS, P., MINOTTI, P.G., MORANDEIRA, N.S., GRIMSON, R., GONZÁLEZ TRILLA, G., GONZÁLEZ, E.B., SAN MARTÍN, L. and GAYOL, M.P. Remote sensing of wetlands in South America: status and challenges. International Journal of Remote Sensing, 2017, 39(4), 993-1016. http:// dx.doi.org/10.1080/01431161.2017.1395971.

KREVŠ, A. and KUČINSKIENE, A. Influence of invasive Acer negundo leaf litter on benthic microbial abundance and activity in the littoral zone of a temperate river in Lithuania. Knowledge and Management of Aquatic Ecosystems, 2017, 418, 418-426. http://dx.doi.org/10.1051/kmae/2017015.

LETA, J. and CHAIMOVICH, H. Recognition and international collaboration: The Brazilian case. Scientometrics, 2002, 53(3), 325-335. http://dx.doi. org/10.1023/A:1014868928349.

LI, Q., MOORHEAD, D.L., DEFOREST, J.L., HENDERSON, R., CHEN, J. and JENSEN, R. Mixed litter decomposition in a managed Missouri Ozark forest ecosystem. Forest Ecology and Management, 2009, 257(2), 688-694. http://dx.doi. org/10.1016/j.foreco.2008.09.043.

LIGEIRO, R., MORETTI, M.S., GONÇALVES JUNIOR, J.F. and CALLISTO, M. What is more important/ for invertebrate colonization in a stream with low-quality litter inputs: exposure time or leaf species? Hydrobiologia, 2010, 654(1), 125-136. http://dx.doi.org/10.1007/s10750-010-0375-8.

LIU, X., ZHANG, L. and HONG, S. Global biodiversity research during 1900-2009: a bibliometric analysis. 
Biodiversity and Conservation, 2011, 20(4), 807-826. http://dx.doi.org/10.1007/s10531-010-9981-z.

MAY, R.M. The scientific wealth of nations. Science, 1997 , 275(5301), 793-796. http://dx.doi.org/10.1126/ science.275.5301.793.

MELO, A.S., BINI, L.M. and CARVALHO, P. Brazilian articles in international journals on Limnology. Scientometrics, 2006, 67(2), 187-199. http://dx.doi. org/10.1007/s11192-006-0093-1.

NERES-LIMA, V., BRITO, E.F., KRSULOVIĆ, F.A., DETWEILER, A.M., HERSHEY, A.E. and MOULTON, T.P. High importance of autochthonous basal food source for the food web of a Brazilian tropical stream regardless of shading. International Review of Hydrobiology, 2016, 101(3-4), 132-142. http://dx.doi.org/10.1002/iroh.201601851.

NERES-LIMA, V., MACHADO-SILVA, F., BAPTISTA, D.F., OLIVEIRA, R.B., ANDRADE, P.M., OLIVEIRA, A.F., SASADA-SATO, C.Y., SILVAJÚNIOR, E.F., FEIJÓ-LIMA, R., ANGELINI, R., CAMARGO, P.B. and MOULTON, T.P. Allochthonous and autochthonous carbon flows in food webs of tropical forest streams. Freshwater Biology, 2017, 62(6), 1012-1023. http://dx.doi. org/10.1111/fwb.12921.

NEVES, T.K., LAVARDA, R.A.B. and MARTINS, C.B. Práticas estratégicas de internacionalização de programas de pós-graduação: estudo de caso em uma universidade pública do Sul do Brasil. Revista Eletronica de Negócios Internacionais, 2019, 14(2), 93-110. http://dx.doi.org/10.18568/internext. v14i2.465.

OLIVEIRA-FILHO, A., BUDKE, J.C., JARENKOW, J.A., EISENLOHR, P.V. and NEVES, D.R.M. Delving into the variations in tree species composition and richness across South American subtropical Atlantic and Pampean forests. Journal of Plant Ecology, 2015, 8(3), 242-260. http://dx.doi. org/10.1093/jpe/rtt058.

PADIAL, A.A., BINI, L.M. and THOMAZ, S.M. The study of aquatic macrophytes in Neotropics: a scientometrical view of the main trends and gaps. Brazilian Journal of Biology $=$ Revista Brasileira de Biologia, 2008, 68(4, Suppl.), 1051-1059. http:// dx.doi.org/10.1590/S1519-69842008000500012. PMid:19197475.

PEREIRA, S.A., TRINDADE, C.R.T., ALBERTONI, E.F. and PALMA-SILVA, C. Aquatic macrophytes as indicators of water quality in subtropical shallow lakes, Southern Brazil. Acta Limnologica Brasiliensia, 2012, 24(1), 52-63. http://dx.doi.org/10.1590/ S2179-975X2012005000026.

PIECZYŃSKA, E. Sources and fate of detritus in the shore zone of lakes. Aquatic Botany, 1986, 25, 153-166. http://dx.doi.org/10.1016/03043770(86)90051-3.

QUIROS, R. Predictors of relative fish biomass in lakes and reservoirs of Argentina. Canadian Journal of
Fisheries and Aquatic Sciences, 1990, 47(5), 928-939. http://dx.doi.org/10.1139/f90-107.

R CORE TEAM R: A language and environment for statistical computing. Vienna: R Foundation for Statistical Computing, 2019. Available from: http:// www.R-project.org/.

RAJA, H.A., SHEARER, C.A. and TSUI, C.K.-M. Freshwater Fungi. Chichester: John Wiley \& Sons, Ltd, 2018. http://dx.doi.org/10.1002/9780470015902. a0027210

REGALADO, A. Brazilian science: Riding a gusher. Science, 2010, 330(6009), 1306-1312. http:// dx.doi.org/10.1126/science.330.6009.1306. PMid:21127226.

SIDONE, O.J.G., HADDAD, E.A. and MENACHALCO, J.P. A ciência nas regióes brasileiras: evolução da produção e das redes de colaboração científica. Transinformação, 2016, 28(1), 15-32. http:// dx.doi.org/10.1590/2318-08892016002800002.

SILVA, W.M. and PERBICHE-NEVES, G. Trends in freshwater microcrustaceans studies in Brazil between 1990 and 2014. Brazilian Journal of Biology = Revista Brasileira de Biologia, 2017, 77(3), 526534. http://dx.doi.org/10.1590/1519-6984.17915. PMid:27925015.

SONG, N., YAN, Z.S., CAI, H.Y. and JIANG, H.L. Effect of temperature on submerged macrophyte litter decomposition within sediments from a large shallow and subtropical freshwater lake. Hydrobiologia, 2013, 714(1), 131-144. http://dx.doi.org/10.1007/s10750013-1529-2.

SUBERKROPP, K. and KLUG, M.J. Fungi and bacteria associated with leaves during processing in a woodland stream. Ecology, 1976, 57(4), 707-719. http://dx.doi.org/10.2307/1936184.

TELÖKEN, F., ALBERTONI, E.F. and PALMASILVA, C. Leaf degradation of Salix humboldtiana Willd. (Salicaceae) and invertebrate colonization in a subtropical lake (Brazil). Acta Limnologica Brasiliensia, 2011, 23(1), 30-41. http://dx.doi. org/10.4322/actalb.2011.016.

TELÖKEN, F., ALBERTONI, E.F., HEPP, L.U. and PALMA-SILVA, C. Aquatic invertebrates associated with Salix humboldtiana litter in a subtropical stream. Ecología Austral, 2014, 24, 220-228. http://dx.doi. org/10.25260/EA.14.24.2.0.25.

TIEGS, S.D., COSTELLO, D.M., ISKEN, M.W., WOODWARD, G., MCINTYRE, P.B., GESSNER, M.O., CHAUVET, E., GRIFFITHS, N.A., FLECKER, A.S., ACUÑA, V., ALBARIÑO, R., ALLEN, D.C., ALONSO, C., ANDINO, P., ARANGO, C., AROVIITA, J., BARBOSA, M.V.M., BARMUTA, L.A., BAXTER, C.V., BELL, T.D.C., BELLINGER, B., BOYERO, L., BROWN, L.E., BRUDER, A., BRUESEWITZ, D.A., BURDON, F.J., CALliSTO, M., CANHOTO, C., CAPPS, K.A., CASTILLO, M.M., CLAPCOTT, J., COLAS, F., COLÓN-GAUD, C., CORNUT, J., 
CRESPO-PÉREZ, V., CROSS, W.F., CULP, J.M., DANGER, M., DANGLES, O., EYTO, E., DERRY, A.M., VILLANUEVA, V.D., DOUGLAS, M.M., ELOSEGI, A., ENCALADA, A.C., ENTREKIN, S., ESPINOSA, R., ETHAIYA, D., FERREIRA, V., FERRIOL, C., FLANAGAN, K.M., FLEITUCH, T., SHAH, J.J.F., FRAINER, A., FRIBERG, N., FROST, P.C., GARCIA, E.A., LAGO, L.G., SOTO, P.E.G., GHATE, S., GILING, D.P., GILMER, A., GONÇALVES JUNIOR, J.F., GONZALES, R.K., GRAÇA, M.A.S., GRACE, M., GROSSART, H.P., GUÉROLD, F., GULIS, V., HEPP, L.U., HIGGINS, S., HISHI, T., HUDDART, J., HUDSON, J., IMBERGER, S., INIIGUEZ-ARMIJOS, C., IWATA, T., JANETSKI, D.J., JENNINGS, E., KIRKWOOD, A.E., KONING A.A., KOSTEN, S., KUEHN, K.A., LAUDON, H., LEAVITT, P.R., SILVA, A.L.L., LEROUX, S.J., LEROY, C.J., LISI, P.J., MACKENZIE, R., MARCARELLI, A.M., MASESE, F.O., MCKIE, B.G., MEDEIROS, A.O., MEISSNER, K., MILIŠA, M., MISHRA, S., MIYAKE, Y., MOERKE, A., MOMBRIKOTB, S., MOONEY, R., MOULTON, T., MUOTKA, T., NEGISHI, J.N., NERES-LIMA, V., NIEMINEN, M.L., NIMPTSCH, J., ONDRUCH, J., PAAVOLA, R., PARDO, S., PEETERS, P.C.J., POZO, J., PRINGLE, C., PRUSSIAN, A., QUENTA, E., QUESADA, A., REID, B., RICHARDSON, J.S., RIGOSI, A., RINCÓN, J., RÎȘNOVEANU, G., ROBINSON, C.T., RODRÍGUEZ-GALLEGO, L., ROYER, T.V., RUSAK, J.A., SANTAMANS, A.C., SELMECZY, G.B., SIMIYU, G., SKUJA,, A., SMYKLA, J., SRIDHAR, K.R., SPONSELLER, R., STOLER, A., SWAN, C.M., SZLAG, D., MELLO, F.T., TONKIN, J.D., UUSHEIMO, S., VEACH, A.M., VILBASTE, S., VOUGHT, LBM., WANG, C., WEBSTER, J.R., WILSON, P.B., WOELFL, S., XENOPOULOS, M.A., YATES, A.G., YOSHIMURA, C., YULE, C.M., ZHANG, Y.X., and ZWART, J.A. Global patterns and drivers of ecosystem functioning in rivers and riparian zones. Science Advances, 2019, 5(1), 1-5. http://dx.doi. org/10.1126/sciadv.aav0486.

TONELLO, G., NAZILOSKI, L.A., TONIN, A.M., RESTELLO, R.M. and HEPP, L.U. Effect of Phylloicus on leaf breakdown in a subtropical stream. Limnetica, 2016, 35(1), 243-252.

TONIN, A.M., HEPP, L.U. and GONÇALVES, J.F. Spatial variability of plant litter decomposition in stream networks: from litter bags to watersheds. Ecosystems, 2018, 21(3), 567-581. http://dx.doi. org/10.1007/s10021-017-0169-1.
TONIN, A.M., HEPP, L.U., RESTELLO, R.M. and GONÇALVES JUNIOR, J.F. Understanding of colonization and breakdown of leaves by invertebrates in a tropical stream is enhanced by using biomass as well as count data. Hydrobiologia, 2014, 740(1), 7988. http://dx.doi.org/10.1007/s10750-014-1939-9.

TOURINHO, M.P., COSTA, A.P., MARTINS, K.P., BANDEIRA, M.G.S. and BARBOSA, F.G. Scientific knowledge on threatened species of the Brazilian Red List: freshwater fish as case study. Environmental Biology of Fishes, 2020, 103(6), 719-731. http:// dx.doi.org/10.1007/s10641-020-00978-5.

TREVISAN, A. and HEPP, L.U. Dinâmica de componentes químicos vegetais e fauna associada ao processo de decomposição de espécies arbóreas em um riacho do norte do Rio Grande do Sul, Brasil. Neotropical Biology and Conservation, 2007, 2(1), 55-60.

VANNOTE, R.L., MINSHALL, G.W., CUMMINS, K.W., SEDELL, J.R. and CUSHING, C.E. The river continuum concept. Canadian Journal of Fisheries and Aquatic Sciences, 1980, 37(1), 130-137. http:// dx.doi.org/10.1139/f80-017.

WALZ, N. Publications of BRIC- and Outreach Countries in International Journals on Limnology. International Review of Hydrobiology, 2010, 95(4-5), 298-312. http://dx.doi.org/10.1002/iroh.201011243.

WARD, J.V. and STANFORD, J.A. Thermal responses in the evolutionary ecology of aquatic insects. Annual Review of Entomology, 1982, 27(1), 97-117. http:// dx.doi.org/10.1146/annurev.en.27.010182.000525.

WEBSTER, J.R. and BENFIELD, E.F. Vascular plant breakdown in freshwater ecosystems. Annual Review of Ecology and Systematics, 1986, 17(1), 567-594. http://dx.doi.org/10.1146/annurev. es.17.110186.003031.

World Bank. World development indicators database [online]. 2021, [viewed 16 Jan. 2021]. Available from: http://data.world bank.org.

YULE, C.M., LEONG, M.Y., LIEW, K.C., RATNARAJAH, R., SCHMIDT, K., WONG, H.M., PEARSON, R.G. and BOYERO, L. Shredders in Malaysia: abundance and richness are higher in cool upland tropical streams. Journal of the North American Benthological Society, 2009, 28(2), 404-441. http://dx.doi.org/10.1899/07-161.1.

Received: 25 March 2020 Accepted: 09 March 2021

Associate Editor: Fabiana Schneck. 